\title{
Quality of Extensive Brackish Water Polyculture Farm Effluents at Different Production Levels and its Impact on the Receiving Environment
}

\author{
Deepta Chakravartty ${ }^{* 1}$, Asish Mondal ${ }^{1}$, Jitendra Kumar Sundaray ${ }^{2}$ \\ SubhraBikash Bhattacharyya ${ }^{1}$, Abhijit Mitra ${ }^{3}$ \\ ${ }^{I}$ Department of Oceanography, Techno India University, Salt Lake campus, Kolkata, India \\ ${ }^{2}$ ICAR-Central Institute of Freshwater Aquaculture, Kausalyaganga, Bhubaneswar-751 002, India \\ ${ }^{3}$ Department of Marine Science, University of Calcutta, 35 B.C. Road, Kolkata - 700019, India
}

*Corresponding Author: Deepta Chakravartty, Department of Oceanography, Techno India University, Salt Lake campus, Kolkata, India

\begin{abstract}
Traditional brackish water aquaculture farms in North 24 Parganas district of West Bengal, India receive sewage water from Kolkata metropolitan city through Bidyadhari River and its tributaries diluted by mixing with sea water. These areas play important ecological role by improving water quality, through conversion of nutrient load into fish biomass. Efforts are underway by farmers to increase production by increasing stocking density of fishes along with fertilizer and feed application. Effects of production levels of enhanced low $(1.62 \pm 0.12$, EL), medium $(2.34 \pm 0.09$, EM) and high $(2.93 \pm 0.21$, EH) over existing production level of $0.87 \pm 0.06$ (EC) tons/ha/year on the effluent quality compared to source water (SW) was studied for 10 months production cycle. Dissolved oxygen concentration and $\mathrm{pH}$ was similar in effluents from EC, EL and EM while those were significantly $(p<0.05)$ low in SW and EH. Chemical oxygen demand $(C O D)$ of effluents from EC and EL were similar and ranged between 10.97-12.02 ppm whereas significantly $(p<0.05)$

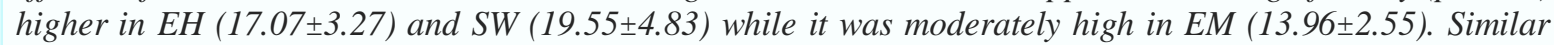
trend has been observed in case of NO3-N, NO2-N, NH4-N and PO4-P. A drastic depletion of bacterial population was observed in all treatments compared to SW. Production from this system can be increased up to 2.34 tons/ ha/ year keeping intact the ecological role.
\end{abstract}

Keywords: Brackish water polyculture, Production level, Effluent, Receiving environment.

\section{INTRODUCTION}

Effluent from vast expanses of aquaculture farms can have major environmental consequences based on intensive culture and the pressure on fish production. Use of commercial feed and fertilizers increases the nutrient, plankton, suspended solids concentration along with BOD (biological oxygen demand) of pond discharge water in contrast to the receiving waters [1,2]. As a remedy to this ecological impact, there are a few aquaculture technologies such as integrated agriculture-aquaculture systems (IAAS) and integrated multi-trophic aquaculture (IMTA) propose a proper utilization of commercial feed by the various farmed animals and plants in the system, thereby reducing the nutrient load in the discharge water $[3,4,5,6]$. The steady implementation of such technology is either too futuristic or complex although it is been tested in coastal regions of Philippines in aqua silviculture programmes with success $[7,8]$.

Brackish water farming in India is an age-old system confined mainly to the 'bheries' (manmade impoundments in coastal wetlands) of West Bengal and 'pokkali' (salt resistant deepwater paddy) fields along the Kerala coast. With no additional input, except that of trapping the naturally bred juvenile fish and shrimp seed, these systems have been sustaining production levels of between 500$750 \mathrm{~kg} / \mathrm{ha} /$ year with shrimp contributing 20-25 percent of the total [9].

Aquaculture has essentially been a traditional practice in the state of West Bengal [10]. In this traditional method, low lying areas near the banks of saline water rivers and creeks are encircled by peripheral dyke and tidal water is allowed to enter in the impoundment along with natural seeds of 
various species of shrimps, crabs and fishes. Water is retained with periodical exchanges during lunar cycles and the animals are allowed to grow. After 3-4 months harvesting is done partially during lunar cycles. Productivity in this system ranges between $400-900 \mathrm{~kg} / \mathrm{ha} / \mathrm{year}$ [11]. Modification of this system of aquaculture with selective stocking, feeding and application of better management practices is yielding much better production. Improved poly-farming of non-carnivorous fishes (e.g. mullets and milk fish) with tiger shrimp has been proved to be a viable alternative to mono-shrimp farming as a low cost-low risk and high profit $[12,13]$.

Potential brackish water area available in the state of West Bengal is 210000 ha of which 47588 ha is under use at present. Area coverage under use in North 24 Parganas district is 34500 ha and traditional brackish water aqua farming is practiced exclusively in this district [14] which plays significant role in the state's economy. Unlike other brackish water areas in the state, these areas distributed mainly in Haroa, Minakhan and Sandeshkhali blocks receive sewage water from Kolkata metropolitan city through Bidyadhari River and its tributaries diluted by mixing with sea water. Production from these areas is in the higher side and ranges between 0.7-0.9 tons/ha/year due to higher nutrient profile of water compared to traditional brackish water aquaculture production (0.4-0.6 tons/ha/year) in other areas where sewage is unavailable. These areas play significant ecological role by improving quality of water through conversion of nutrient load into fish biomass [11]. Less polluted effluent is discharged in the receiving water body than the source water. As increment in production is needed to meet increased demand and to improve profitability, some progressive farmers are trying to increase production by increasing stocking density and with application of farm made or commercially available feed. There is scarcity of information on the consequences of intensification in such ecologically unique and important areas. This study was conducted to assess quality of effluent discharged from improved traditional aquaculture impoundments at different production levels compared to source water and to identify sustainable production level keeping intact the ecological role of the system.

\section{MATERials AND MethodS}

The study was carried out at three locations namely Atghara $\left(22.6107^{\circ} \mathrm{N}, 88.6902^{\circ} \mathrm{E}\right)$, Vikharait $\left(22.6178^{\circ} \mathrm{N}, 88.6963^{\circ} \mathrm{E}\right)$ and Goberia $\left(22.6195^{\circ} \mathrm{N}, 88.7059^{\circ} \mathrm{E}\right)$ areas of Haroa block in North 24 Parganas, West Bengal. In each locations, 4 impoundments (0.16-0.21 ha) were used for trial in different targeted production levels. 20-30\% water was exchanged every lunar cycle following the common practice. Quality of source water (SW), effluents from impoundments with existing production level (EC) of 0.7-0.9 tons/ ha/ year treated as control and targeted production levels of enhanced low (1.5-1.7tons/ ha/ year, EL), medium (2.3-2.5tons/ ha/ year, EM) and high (3.1-3.3tons/ ha/ year, EH) were evaluated fortnightly for a period of 10 (February-December, 2013) months during every full moon and new moon.

An interview based survey revealed that in addition to auto stocked fishes and shrimps; farmers generally stock pre-nursed fingerlings of grey mullet (Mugil cephalus), tade mullet (Liza tade), parsia (Liza parsia) and tilapia (Oreochromis nilotica and O. mossumbica) @ 250, 500, 1000 and 500 numbers/ ha respectively during the month of February. Multiple stocking of tiger shrimp is done @ 5000/ ha monthly during full moon or new moon starting from February till September. Partial harvest of shrimp starts during April and continued every lunar cycle. Fishes are generally harvested at the time of dewatering during December. Increment in production was achieved by increasing stocking density 2, 3 and 4 times of generally practiced stocking protocol and application of farm made dough feed (Protein: 22\%, Crude fat: 3\%) @ 10-1\% of estimated biomass in all impoundments except those with existing production level (EC). Agricultural lime $\left(\mathrm{CaCO}_{3}\right)$ was applied in all impoundments fortnightly @ $50 \mathrm{Kg} /$ ha after water exchanges. Stocking density of different species in different treatments is presented in table 1. Monthly sampling was carried out to estimate fish and shrimp biomass.

Physico-chemical and microbiological parameters of source water and effluents from different production levels were analyzed following standard methods [15]. Quantitative estimation of phytoplankton and zooplankton was done by "Direct census method" [16]. Water samples from source were collected before exchanges and effluents were collected during discharge from the impoundments. 
Quality of Extensive Brackish Water Polyculture Farm Effluents at Different Production Levels and its Impact on the Receiving Environment

Table 1. Stocking density (numbers/ ha) of fishes and tiger shrimp in existing low production level of 0.70.9tons/ ha/ year treated as control (EC) and targeted enhanced production levels of low (1.5-1.7 tons/ ha/ year, EL), medium (2.3-2.5 tons/ ha/ year, EM) and high (3.1-3.3 tons/ ha/ year, EH) in traditional brackish water impoundments

\begin{tabular}{|l|c|c|c|c|}
\hline Species & EC & EL & EM & EH \\
\hline Grey mullet & 250 & 500 & 750 & 1000 \\
\hline Tade mullet & 500 & 1000 & 1500 & 2000 \\
\hline Parsia & 1000 & 2000 & 3000 & 4000 \\
\hline Tilapia & 500 & 1000 & 1500 & 2000 \\
\hline Tiger shrimp (monthly) & 5000 & 10000 & 15000 & 20000 \\
\hline
\end{tabular}

Differences of each parameter among treatments were determined by analysis of variance with the General Linear Model procedure using SPSS for Windows v.17.0 programme (SPSS Inc., Chicago, IL, USA). Duncan's Multiple Range Test [17] was used for comparison of treatments. All data are expressed as mean \pm standard error (S.E.).

\section{RESULTS AND DISCUSSION}

A comparative account of physico-chemical parameters in source water and effluents from different treatments are summarized in table $\mathbf{2}$ and monthly variations are depicted in figure 1. Salinity and temperature were insignificantly different in source water and effluent samples which ranged between 16.3-0.2 ppt and 33.0-18.0 ${ }^{\circ} \mathrm{C}$, respectively over time. Although, water temperature and salinity are reported to have significant effect on growth in various cultivable aquatic organisms and other water quality parameters [18, 19], any effect that might have occurred would have been equal to all four treatments and source water, meaning differences can be attributed to the varied farming systems only.

Table 2. Physico-chemical parameters of source water and effluents from production levels of existing (0.87 \pm 0.06 tons/ ha/ year, EC), enhanced low (1.62 \pm 0.12 tons/ ha/ year, EL), medium (2.34 \pm 0.09 tons/ ha/ year, EM) and high (2.93 \pm 0.21 tons/ ha/ year, EH) in sewage fed traditional brackish water polyculture

\begin{tabular}{|l|c|c|c|c|c|}
\hline Water parameters & SW & EC & EL & EM & EH \\
\hline Temperature $\left.{ }^{\circ} \mathrm{C}\right)$ & $29.8 \pm 1.8$ & $29.9 \pm 1.7$ & $29.9 \pm 1.7$ & $29.7 \pm 1.9$ & $29.8 \pm 1.7$ \\
\hline Salinity $\left(\mathrm{g} \mathrm{L}^{-1}\right)$ & $8.86 \pm 3.35$ & $8.87 \pm 3.34$ & $8.84 \pm 3.32$ & $8.89 \pm 3.19$ & $8.85 \pm 3.24$ \\
\hline $\mathrm{pH}$ & $7.61 \pm 0.21^{\mathrm{c}}$ & $8.24 \pm 0.23^{\mathrm{a}}$ & $8.19 \pm 0.25^{\mathrm{a}}$ & $8.17 \pm 0.31^{\mathrm{a}}$ & $7.82 \pm 0.27^{\mathrm{b}}$ \\
\hline $\mathrm{DO}\left(\mathrm{mg} \mathrm{L}^{-1}\right)$ & $4.89 \pm 1.95^{\mathrm{c}}$ & $5.94 \pm 1.45^{\mathrm{a}}$ & $5.79 \pm 1.22^{\mathrm{a}}$ & $5.73 \pm 1.98^{\mathrm{a}}$ & $5.19 \pm 1.87^{\mathrm{b}}$ \\
\hline $\mathrm{COD}\left(\mathrm{mg} \mathrm{L}^{-1}\right)$ & $19.55 \pm 4.83^{\mathrm{a}}$ & $11.33 \pm 2.62^{\mathrm{c}}$ & $11.91 \pm 2.98^{\mathrm{c}}$ & $13.17 \pm 3.01^{\mathrm{bc}}$ & $17.07 \pm 3.27^{\mathrm{b}}$ \\
\hline $\mathrm{NO}_{2}-\mathrm{N}\left(\mu \mathrm{g} \mathrm{L}^{-1}\right)$ & $54.61 \pm 10.62^{\mathrm{a}}$ & $36.71 \pm 6.63^{\mathrm{c}}$ & $36.89 .75 \pm 3.83^{\mathrm{c}}$ & $37.81 \pm 4.93^{\mathrm{c}}$ & $43.09 \pm 6.07^{\mathrm{b}}$ \\
\hline $\mathrm{NO}_{3}-\mathrm{N}\left(\mu \mathrm{g} \mathrm{L}^{-1}\right)$ & $279.46 \pm 11.14^{\mathrm{a}}$ & $172.55 \pm 8.26^{\mathrm{c}}$ & $175.77 \pm 8.94^{\mathrm{c}}$ & $194.12 \pm 15.41^{\mathrm{bc}}$ & $227.91 \pm 30.72^{\mathrm{b}}$ \\
\hline $\mathrm{NH}_{4}-\mathrm{N}\left(\mu \mathrm{g} \mathrm{L}^{-1}\right)$ & $253.17 \pm 66.52^{\mathrm{a}}$ & $193.62 \pm 33.49^{\mathrm{c}}$ & $194.89 \pm 36.27^{\mathrm{c}}$ & $206.16 \pm 44.61^{\mathrm{bc}}$ & $224.19 \pm 52.91^{\mathrm{b}}$ \\
\hline $\mathrm{PO}_{4}-\mathrm{P}\left(\mu \mathrm{g} \mathrm{L}^{-1}\right)$ & $169.11 \pm 8.98^{\mathrm{a}}$ & $101.58 \pm 11.05^{\mathrm{d}}$ & $107.62 \pm 12.74^{\mathrm{c}}$ & $132.67 \pm 16.43^{\mathrm{c}}$ & $145.33 \pm 15.39^{\mathrm{b}}$ \\
\hline
\end{tabular}

Means bearing different superscripts indicate statistically significant differences in a row (p<0.05); Values are expressed as mean $\pm S E$ of three replicate ponds. $N=20$ for all parameters in each treatments

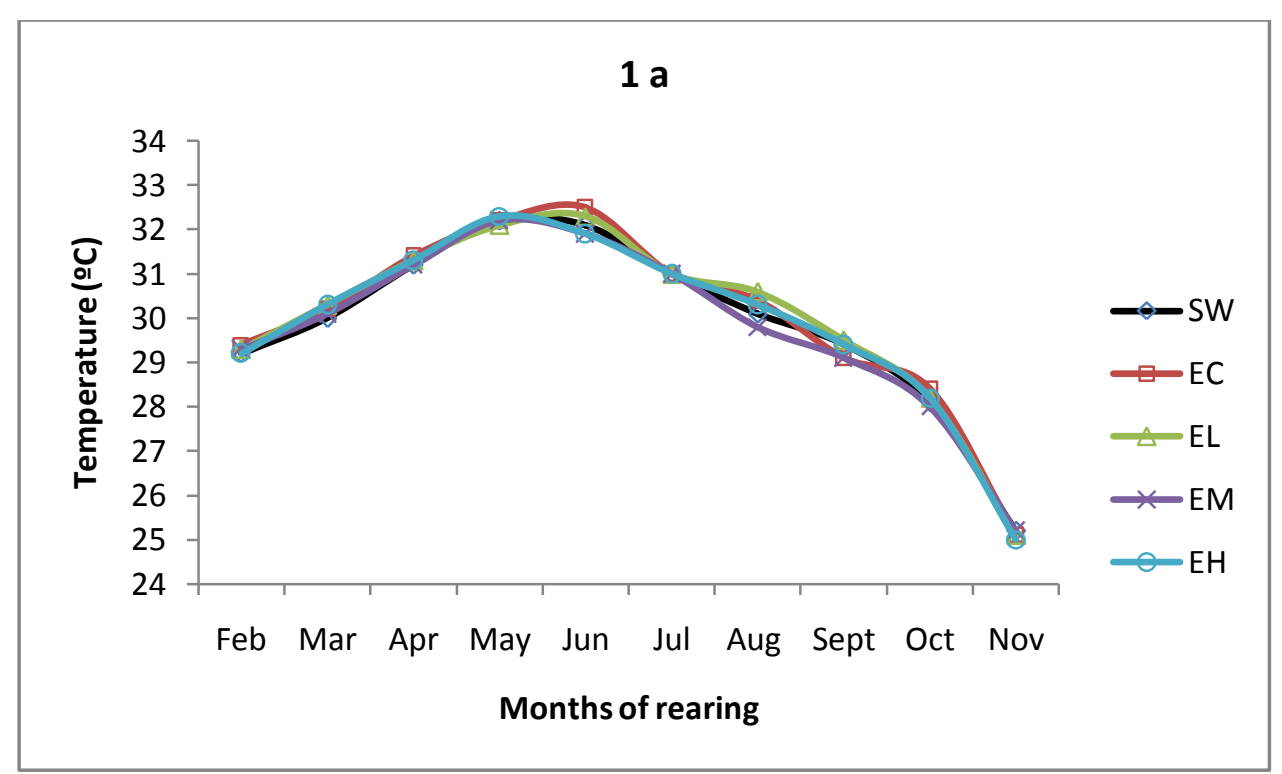



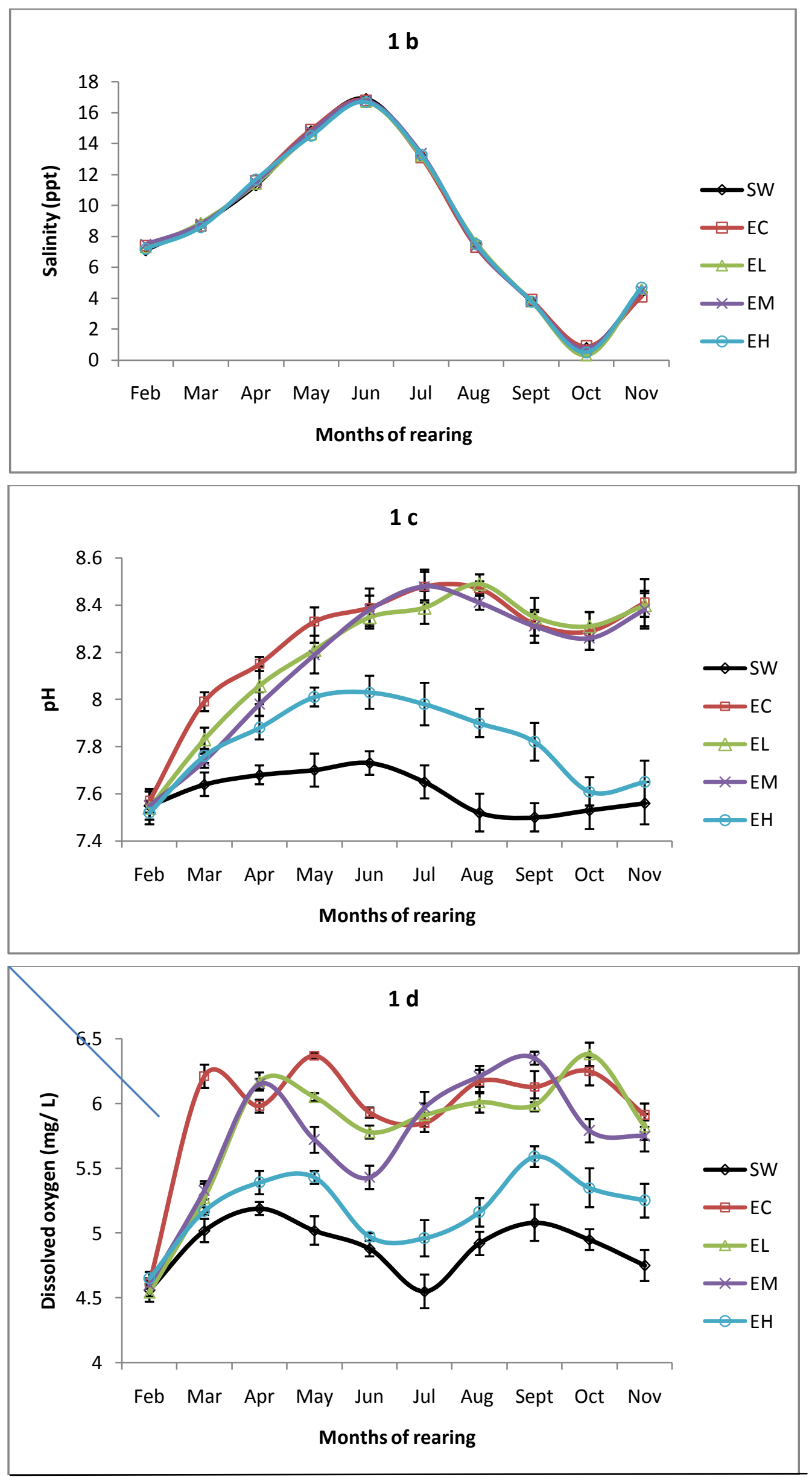

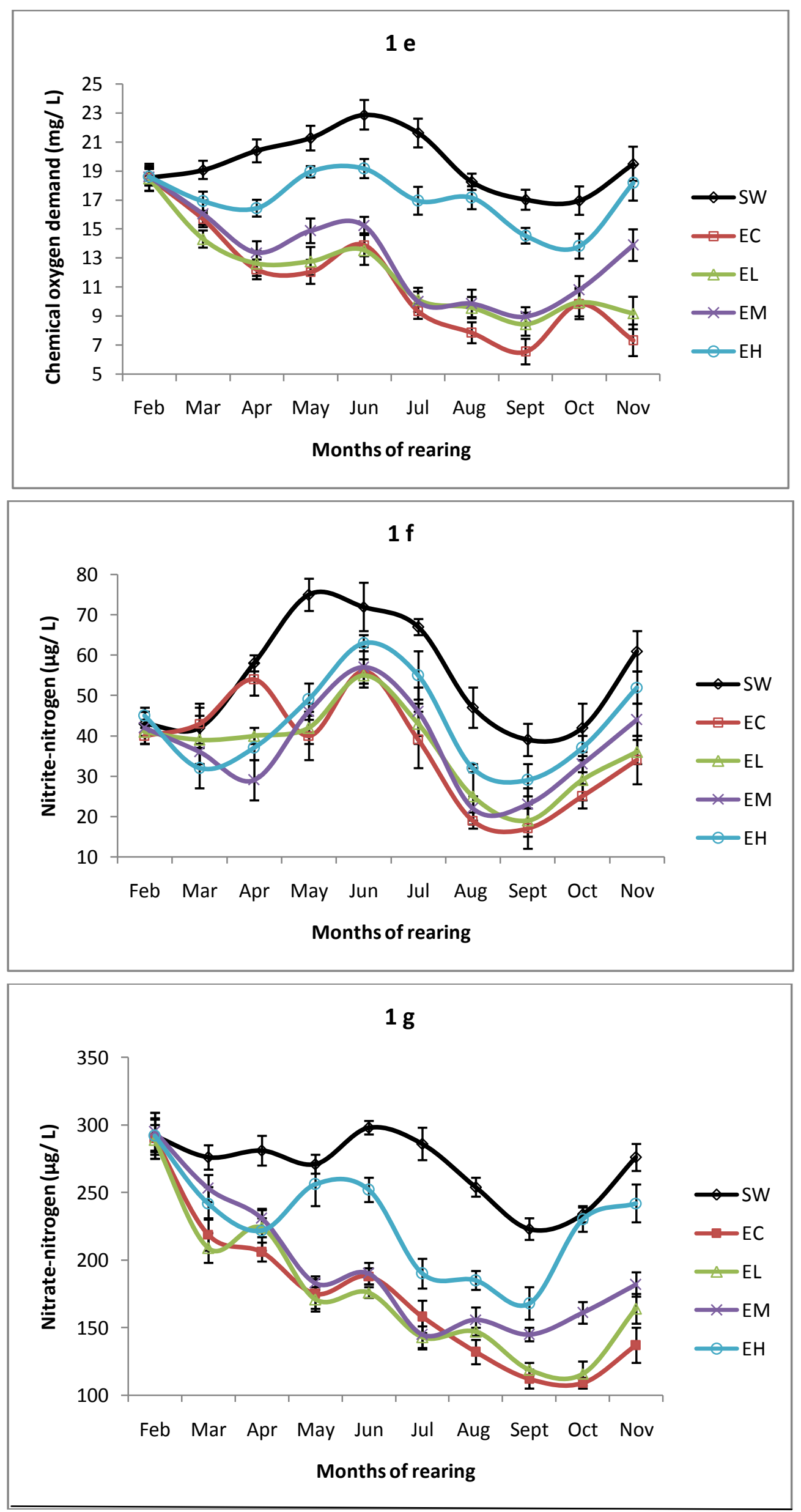

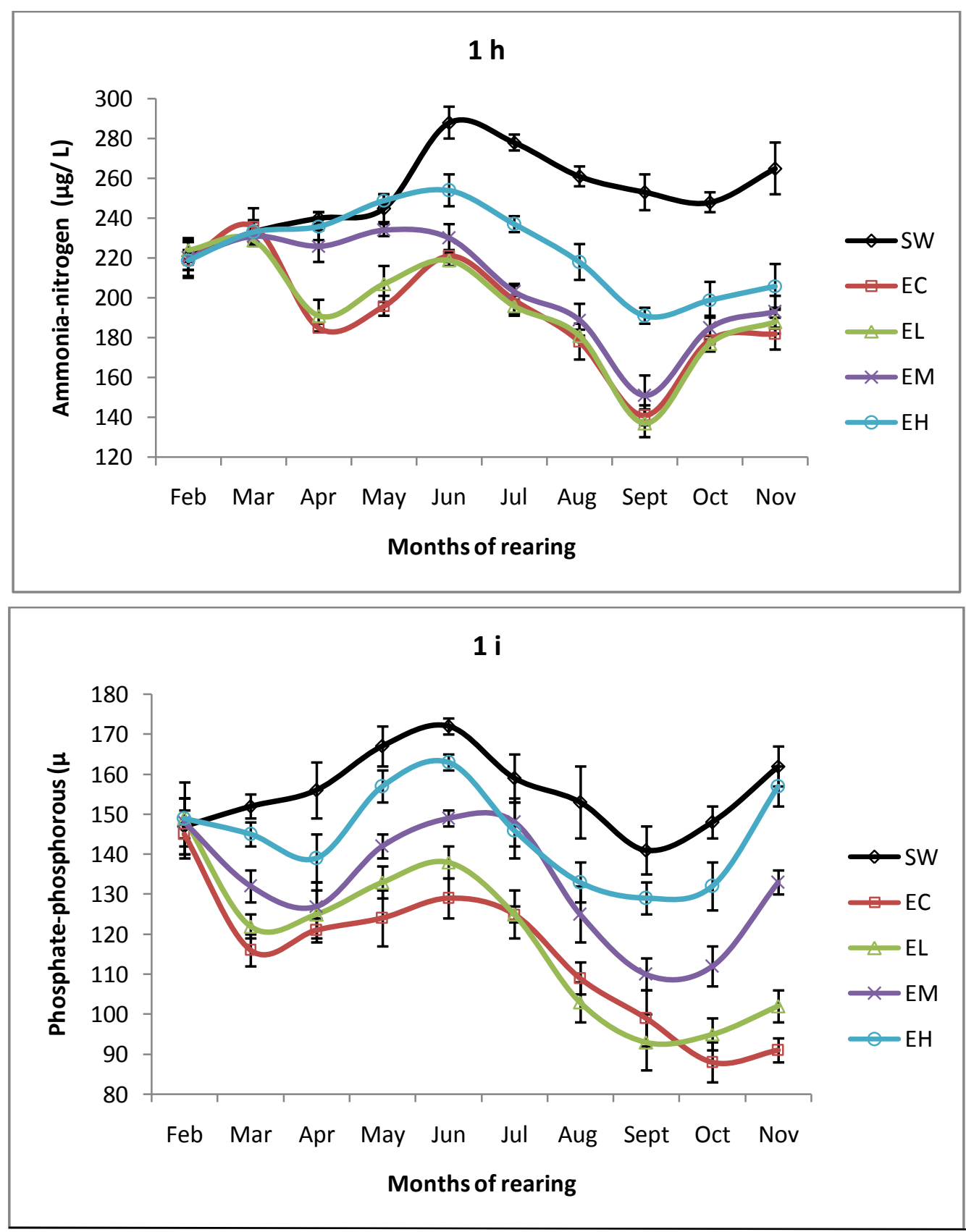

Figure 1 (a-i). Water quality parameters of source water $(S W)$ and effluents from production levels of existing $(0.87 \pm 0.06$ tons/ ha/ year, EC), enhanced low $(1.62 \pm 0.12$ tons/ ha/ year, EL), medium $(2.34 \pm 0.09$ tons/ ha/ year, $E M)$ and high (2.93 \pm 0.21 tons/ ha/ year, EH) in sewage fed traditional brackish water polyculture

Similar pH ranging7.81-8.63 was recorded in samples from EC, EL and EM whereas significantly $(\mathrm{p}<0.05)$ lower $(7.39-8.14)$ values were recorded in SW and EH. Concentration of dissolved oxygen $(\mathrm{ppm})$ showed similar trend with similar values in EC $(5.94 \pm 1.45)$, EL $(5.79 \pm 1.22)$ and EM $(5.73 \pm 1.98)$. Significant $(p<0.05)$ lower dissolved oxygen were observed in SW $(4.89 \pm 1.95)$ and EH $(5.19 \pm 1.87)$. Fortnightly application of lime might have contributed to desirable water quality. The observed higher $\mathrm{pH}$ and dissolved oxygen in effluents may be attributed to no or low nutrient wastage and maintenance of aerobic condition in the presence of autotrophic organisms [20].

Chemical oxygen demand (COD) in EC and EL were similar and ranged between 10.97-12.02 ppm throughout the study period and significantly $(\mathrm{p}<0.01)$ higher COD $(\mathrm{ppm})$ was recorded in EH $(17.07 \pm 3.27)$ and SW (19.55 \pm 4.83$)$ while it was moderately high in EM (12.96 \pm 2.55$)$. COD is considered more scientific than the traditional concept of biochemical oxygen demand (BOD) for determining the organic load of a water body [21]. Significant $(\mathrm{p}<0.05)$ higher value in SW and EH suggests deteriorating condition. The difference could be due to difference in stocking density in 
culture treatments [22]. Table 2 and figure 1 (a-i) depicts similar trend in case of nutrients like nitrate-nitrogen $\left(\mathrm{NO}_{3}-\mathrm{N}\right)$ and phosphate-phosphorous $\left(\mathrm{PO}_{4}-\mathrm{P}\right)$, and toxic nitrogenous metabolites like nitrite-nitrogen $\left(\mathrm{NO}_{2}-\mathrm{N}\right)$ and total ammonia-nitrogen $\left(\mathrm{NH}_{4}-\mathrm{N}\right)$. In estuary and coastal ecosystems, nitrogen was found to be most often the dominant limiting nutrient [23] and is converted into fish biomass through autotrophs. Lower value in EC, EL and EM indicated proper utilization at lower production levels. Nutrients brought with SW and additional nutrients supplied through feed in EL and EM was properly utilized by phytoplankton, macro algae and periphytic algae grown on macroalgae and reduced their level in effluents $[24,25]$. Higher quantity of nutrient supply through feed in EH might have crossed the limit of utilization capacity of the autotrophs. Similar observations have been reported [26] in inland saline groundwater ponds at different doses of fertilization.

Phytoplankton and zooplankton density in SW and all other treatments is presented in figure 2. According to order of dominance, the most abundant phytoplankton groups were Bacillariophyceae, Chlorophyceae, and Myxophyceae. Genera observed under Bacillariophyceae were Navicula, Nitzschia, Cyclotella, Gyrosigma, Melosira, Cymbella, Synedra, Coscinodiscus and Pleurosigma. Genera observed under Chlorophyceae were Pediastrum, Chlorella, Scenedesmus, Tetraedron, Ankistrodesmus, Coilastrum, Crucigenia, and Pandorina. Anabaena, Oscillatoria, Chroococcus, Gleocapsa and Merismopedia were the most dominant genera under Myxophyceae. The dominant zooplankton groups were dinoflagellets and copepods. Common Dinoflagellets genera such as Ceratium and Peridinium and Copepodgenera like Calanus were most plentiful. Rotifers and cladocera existed as less abundant zooplankton groups. Phytoplankton and zooplankton densities were similar in effluents from EC, EL and EM and were significantly $(\mathrm{p}<0.05)$ less than SW and EH. This indicated ambient nutrients in SW to have facilitated the continuous propagation of phytoplankton population [27]. Further increment was observed while integrated with feeding. Lower but steady plankton counts throughout the experimental period in EC, EL and EM may be attributed to competition for resources among phytoplankton and periphyton assemblages whereas plankton population significantly greater in $\mathrm{EH}$ compared to SW indicated excess nutrient beyond utilization. Bacterial population in terms of total heterotrophic bacteria (THB) and total coliform (TC) is presented in figure 3. A drastic depletion of THB and TC in effluents from all the production levels were observed compared to SW (THB: $143.56 \pm 6.41 \times 10^{5} \mathrm{CFU} / \mathrm{ml}$, TC: $119.69 \pm 7.46 \times 10^{2} \mathrm{MPN} / 100$ $\mathrm{ml})$. According to Saha et al [11], lower bacterial load in the effluents of all production levels may be attributed to better pond management and periodical lime application.

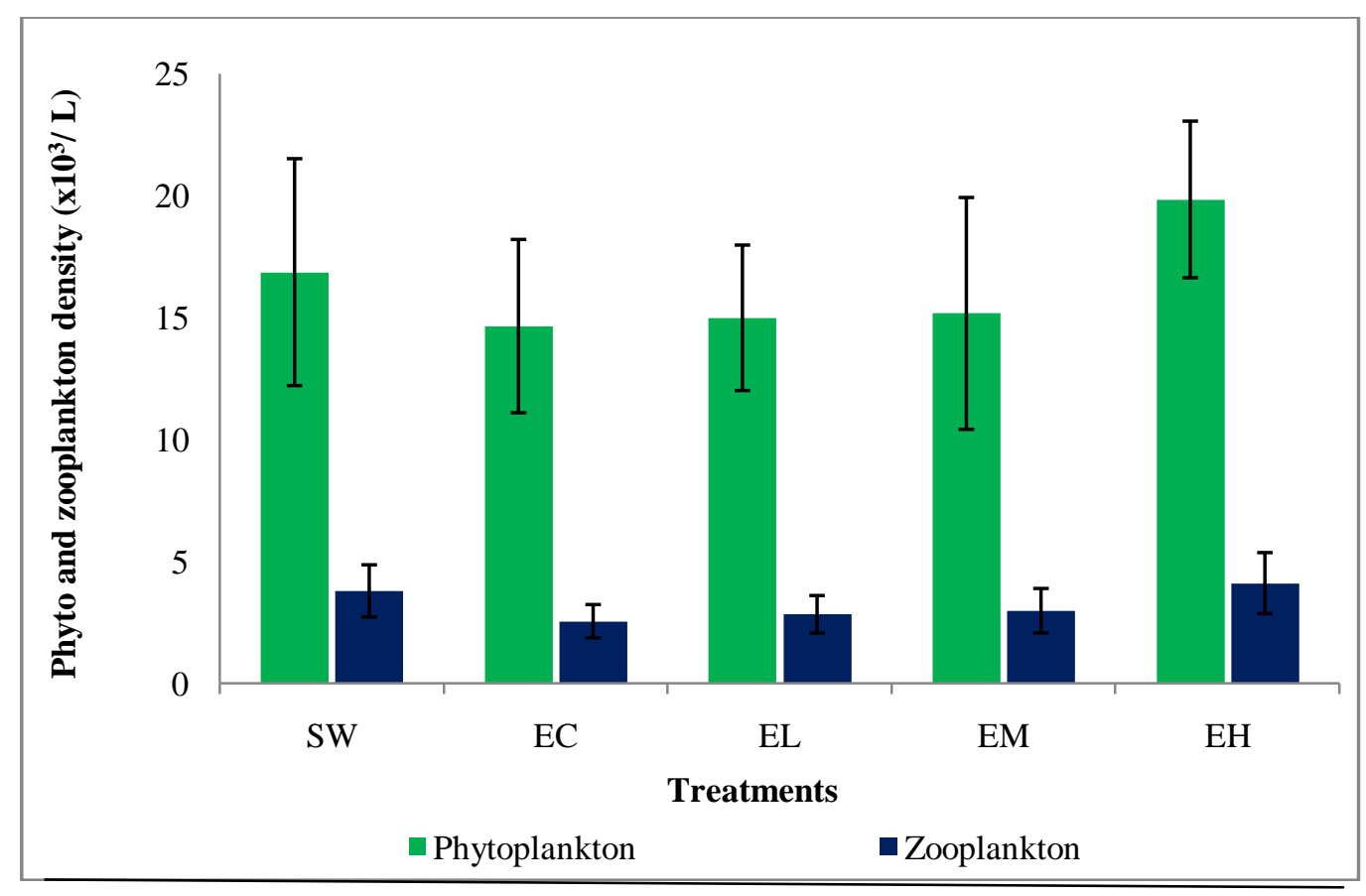

Figure 2. Phytoplankton and Zooplankton density in source water (SW) and effluents from production levels of existing (0.87 \pm 0.06 tons/ ha/ year, EC), enhanced low (1.62 \pm 0.12 tons/ ha/ year, EL), medium (2.34 \pm 0.09 tons/ ha/ year, EM) and high (2.93 \pm 0.21 tons/ ha/ year, EH) in sewage fed traditional brackish water polyculture 


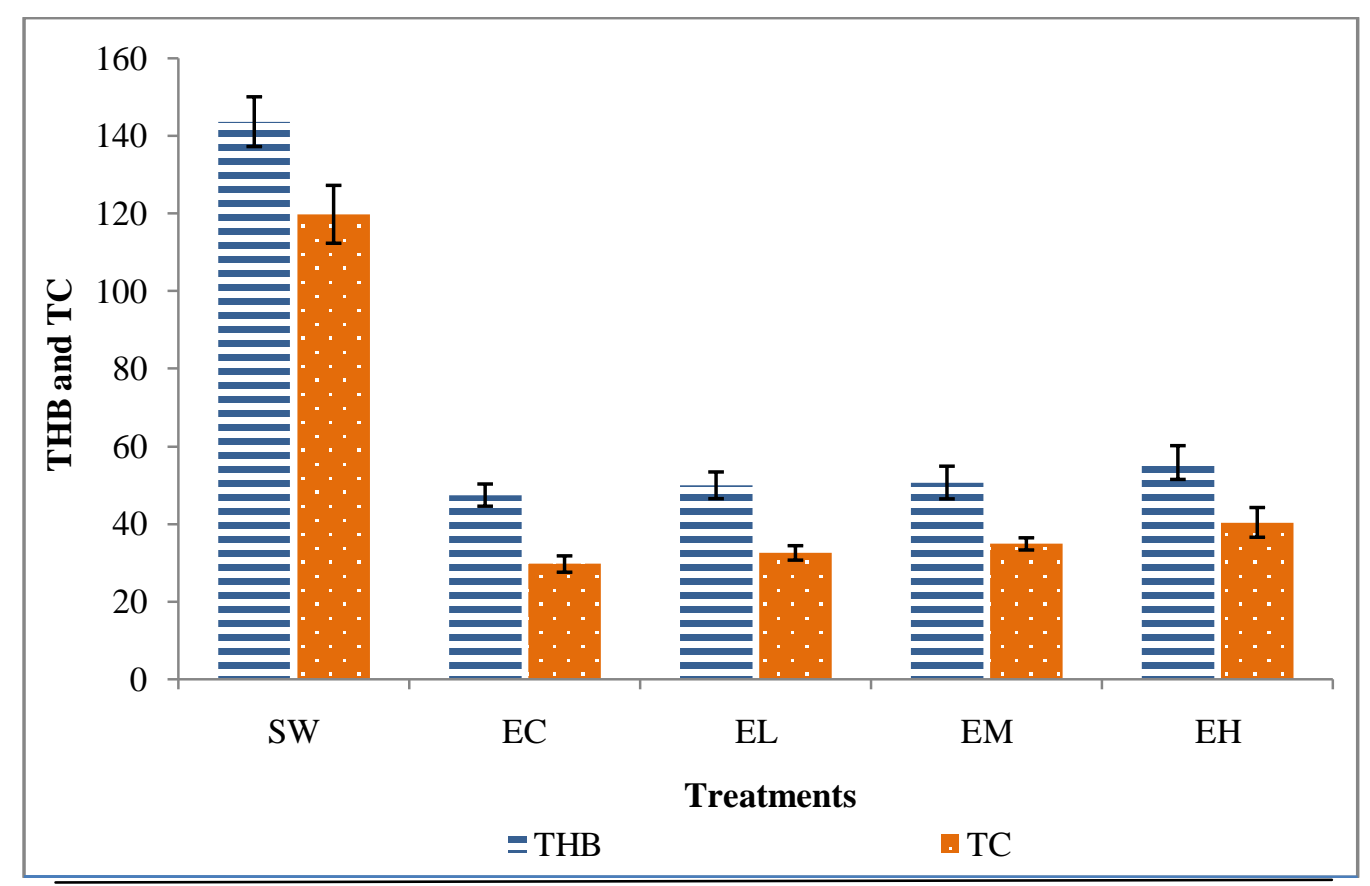

Figure 3. Total Heterotropic bacteria THB $\left(\times 10^{5} \mathrm{CFU} / \mathrm{ml}\right)$ and total Coliform TC $\left(\times 10^{2} \mathrm{MPN} / 100 \mathrm{ml}\right)$ in source water (SW) and effluents from production levels of existing (0.87 \pm 0.06 tons/ ha/ year, EC), enhanced low (1.62 \pm 0.12 tons/ ha/ year, EL), medium $(2.34 \pm 0.09$ tons/ ha/ year, EM) and high $(2.93 \pm 0.21$ tons/ ha/ year, EH) in sewage fed traditional brackish water polyculture

Total production achieved at final harvest was $0.87 \pm 0.06,1.62 \pm 0.12,2.34 \pm 0.09$ and $2.93 \pm 0.21$ tons/ha/year in existing and enhanced low, medium and high production levels respectively. Feed conversion ratio (FCR) achieved was 0.96: 1, 1.14: 1 and 1.51: 1 in low, medium and high production levels. About $26 \%$ of total harvested weight was comprised of tiger shrimp. Achievement of production at the higher side of expectation at low production level and reverse at the higher production expectation might be due to increased stress and competition at higher stocking density [28].

\section{Conclusions}

Sewage fed brackish water aquaculture farms in the studied location indicates its efficiency to improve production to a greater extent without harming its ecological role. Increment in production up to the level of 2.3-2.5 tons/ha year, which is approximately 3 times than the present production level will not affect significantly the water purification capacity of the system. Stocking density aiming production level of 3.1-3.3 tons/ha/year produced effluent of similar quality with source water except less bacterial load may harm the ecological role of the system. Further research is needed to optimize species composition and stocking density of each species for better management of these highly potential and ecologically vulnerable areas.

\section{ACKNOWLEDGEMENTS}

Authors are grateful to the authorities of Techno India University, Kolkata for providing infrastructural facilities and encouragement. Authors also extend thanks to the NatureNerve team, Kolkata for sharing the passion for sustainable aquaculture.

\section{REFERENCES}

[1] Boyd C.E., Guidelines for aquaculture effluent management at the farm-level, Aquacult. 226: 101-112 (2003).

[2] Boyd C.E., and Chainark S., Advances in technology and practice for land-based aquaculture systems: ponds for finfish production. In: Burnell G, Allan G (ed) New technologies in aquaculture: improving production efficiency, quality and environmental management, Woodhead Publishing. Cambridge. Pp. 984-1009 (2009).

[3] McIntosh D., and Fitzsimmons K., Characterization of effluent from an inland, low-salinity shrimp farm: what contribution can this water make if used for irrigation, Aquacult. Engg. 27: 147 - 156 (2003). 
[4] Neori A., Chopin T., Troell M., Buschmann A.H., Kraemer G.P., Halling C, Shpigel M., and Yarish C., Integrated aquaculture: rationale, evolution and state of the art emphasizing seaweed biofiltration in modern mariculture, Aquacult. 231: 361 - 391(2004).

[5] Troell M., Joyce A., Chopin T., Neori A., Buschmann A.H., and Fang J., Ecological engineering in aquaculture - Potential for integrated multi-trophic aquaculture (IMTA) in marine offshore systems, Aquacult. 297: 1 - 9 (2009).

[6] Chopin T., Troell M., Reid G.K., Knowler D., Robinson S.M.C., Neori A., Buschmann A.H., and Pang S., Integrated Multi-Trophic Aquaculture Part II. Increasing IMTA adoption, Global Aquacult. Advocate: 1720(2010).

[7] Gowing J.W., TuongT.P., and Hoanh C.T., Land and water management in coastal zones: dealing with agriculture-aquaculture-fishery conflicts. In: Hoanh CT, Tuong TP, Gowing JW, Hardy B (ed) Environment and livelihoods in tropical coastal zones: managing agriculture-fishery-aquaculture conflicts, Comprehensive assessment of water management in agriculture series 2, CAB International, Wallingford. Pp. 1-16(2006).

[8] Tejada R.L.P., Ranara C.T.B., and Saligan R.B., Community-based mangrove conservation and aquasilviculture: A fishery livelihood and resource conservation project in Davao del Norte. Philippine Agricultural Economics \& Development Association (PAEDA) Biennial Convention. https://paedacon.files.wordpress.com/2013/10/fullpaper_tejada Last accessed 7 February, 2015 (2013).

[9] Food and Agriculture Organization of the United Nations, National Aquaculture Sector Overview, India. http://www.fao.org/fishery/countrysector/naso_india/en/ Last accessed 7 February, 2015 (2014).

[10] Beveridge C.M.M., and Little D.C., The history of aquaculture in traditional societies. In: Costa-Pierce BA (ed) Ecological aquaculture: the evolution of the blue revolution, Blackwell, Oxford. Pp. 3-29 (2002).

[11] Saha S.B., Bhattacharyya S.B., Mitra A., and Choudhury A., Quality of shrimp culture farm effluents and its impact on the receiving environment, Bang. J. Zool. 29(2): 139 - 149(2001).

[12] Joseph I., Abraham M., and Pillai S.M., Polyculture - a viable alternative for less productive tide-fed brackish water ponds, Fishing Chimes. 21(3): 18 - 20 (2001).

[13] Biswas G., Ananda Raja R., De D., Sundaray J.K., Ghoshal T.K., Anand S., Kumar S., Panigrahi A., Thirunavukkarasu A.R., and Ponniah A.G., Evaluation of productions and economic returns from two brackish water polyculture systems in tide-fed ponds, J. App. Ichthyology. 28(1): 116-122 (2012).

[14] Dept. of Animal Husbandry, Dairying \& Fisheries, Fisheries profile of India, Ministry of Agriculture, Government of India. http://www.dahd.nic.in Last accessed 5 February, 2015(2013).

[15] APHA, Standard Methods for the Examination of Water and Wastewater, 20th ed. American Public Health Association, Washington, DC. USA (1998).

[16] Jhingran V.G., Natarajan A.V., Banerjee S.M., and David A., (1969) Methodology on reservoir fisheries investigation in India, Bull. Cent. Inland Fish. Res. Inst. Barrackpore. 12: 1-109 (1969).

[17] Duncan D.B., Multiple range and multiple F-test, Biometrics. 11: 1-42 (1955).

[18] O'Brien C.J., The effects of temperature and salinity on growth and survival of juvenile tiger prawns Penueusesculentus (Haswell). J. Exp. Mar. Biol. Ecol. 183: 133-145 (1994).

[19] Tsuzuki M.Y., Cavalli R.O., and Bianchini A., The effects of temperature, age and acclimation to salinity on the survival of Falfantepenaeus paulensis postlarvae, J. World Aquac. Soc. 31: 459-468 (2000).

[20] Azim M.E., and Little D.C., Intensifying aquaculture production through new approaches to manipulating natural food. CAB Reviews: Perspectives in Agriculture, Veterinary Science, Nutrition and Natural Resources. 1(62): 1-23 (2006).

[21] De A.K., Environmental Chemistry. 3rd edn, Wiley Eastern Ltd, New Delhi, (1995).

[22] Matias H.B., Yusoff F.M., Shariff. M., and Azhar. O., Effects of commercial microbial products on water quality in tropical shrimp culture ponds, Asian Fish. Soc. 15: 239 - 248 (2002).

[23] Paerl H.W., Valdes L.M., Joyner A.R., Piehler M.F., and Lebo M.E., Solving problems resulting from solutions: evolution of a dual nutrient management strategy for the eutrophying Neuse River estuary, North Carolina, Env. Sc. Tech. 38: 3068 - 3073 (2004).

[24] Ramesh M.R., Shankar K.M., Mohan C.V., and Varghese T.J., Comparison of three plant substrates for enhancing carp growth through bacterial biofilm, Aquacult. Engg. 19:119-131(1999).

[25] Ballester E.L.C., Wasielesky W. Jr., Cavalli R.O., and Abreu P.C., Nursery of the pink shrimp Farfantepenaeuspaulensis in cages with artificial substrates: biofilm composition and shrimp performance, Aquacult. 269:355-362 (2007). 
Quality of Extensive Brackish Water Polyculture Farm Effluents at Different Production Levels and its Impact on the Receiving Environment

[26] Garg S.K., Jana S.N., and Arasu A.R.T., Determination of fertilization rate for optimum pond productivity and fish growth in inland saline groundwater ponds: monoculture of grey mullet and milkfish, Asian Fish. Sc. 19: 165-176 (2006).

[27] Mischke C.C., and Zimba P.V., Plankton community responses in earthen channel catfish nursery ponds under various fertilization regimes. Aquacult. 233: 219-235 (2004).

[28] Araneda M., Pérez EP., and Gasca-Leyva., White shrimp Penaeus vannamei culture in freshwater at three densities: Condition state based on length and weight, Aquacult. 283: 13-18 (2008).

Citation: D. Chakravartty et al.," Quality of Extensive Brackish Water Polyculture Farm Effluents at Different Production Levels and its Impact on the Receiving Environment", International Journal of Innovative Studies in Aquatic Biology and Fisheries (IJISABF), vol. 3, no. 2, p. 10, 2017.http://dx.doi.org/ 10.20431/2454-7670.0302002

Copyright: (C) 2017 Authors. This is an open-access article distributed under the terms of the Creative Commons Attribution License, which permits unrestricted use, distribution, and reproduction in any medium, provided the original author and source are credited. 